\title{
Effect of Different Combinations of Tuna Fishmeal, Meat Meal with Bone, and Soybean Meal Upon the Laying Intensity, Egg Quality, and Feed Utilization by Hens ${ }^{1}$
}

\author{
Manuel Rojas-Daporta, Manuel Soldevila, and Lilia L. Gonzáles ${ }^{2}$
}

\begin{abstract}
Three nutritional studies with laying hens and two organoleptic evaluations of the eggs produced are reported. Different combinations of soybean, tuna and meat meals were evaluated using laying intensity and utilization of feed as criteria for comparison. In all studies the groups receiving a combination of equal parts of tuna and soybean meals laid eggs as well or better than the groups fed otherwise. A decrease in overall performance resulted as the level of meat meal was increased.

Organoleptic evaluations showed no differences in the odor of freshly broken uncooked eggs or the flavor of hard-boiled eggs representative of the diets tested. The results indicate that in practical-type laying diets with levels as high as $18 \%$ tuna meal, the only factor that may limit its use is its cost when compared to that of soybean meal or of any other suitable substitute.
\end{abstract}

\section{INTRODUCTION}

Morassi et al. (5) reported good growth with broiler chicks when the protein supplement fraction was composed of equal parts of tuna fishmeal and soybean meal. Similar results were reported (6) with chicks of a laying strain. These results confirmed in general those of Bender and Haizelden (1), Clark et al. (2), March et al. (4), Summers et al. (8) and Waldroup et al. (9).

The objectives of the study herein reported were to determine the optimum combinations of tuna fishmeal, meat meal with bone, and soybean in laying diets with regard to laying rate, egg quality, and feed utilization.

\section{MATERIALS AND METHODS}

Different combinations of tuna fishmeal, meat meal with bone, and soybean meal were evaluated in three studies conducted at the Lajas

${ }^{1}$ Manuscript submitted to Editorial Board August 25, 1975.

${ }^{2}$ Former Animal Husbandman, Lajas Substation, Associate Nutritionist, Animal Husbandry Department, and former Assistant Food Technologist, Food Technology Laboratory, respectively, Agricultural Experiment Station, Mayagüez Campus, University of Puerto Rico, Río Piedras, P.R. 
Substation. Production and feed utilization by Leghorn hens were used as criteria for comparison. Two organoleptic evaluations of the eggs produced in two of the studies are also reported.

In the first study, an unrestricted random design with five treatments replicated three times was used. Each replicate consisted of 25 hens housed in a floor pen $4.55 \times 4.55 \mathrm{~m}$.

In the second and third studies, a complete block design with five treatments, replicated 12 times, was used. Each replicate consisted of one hen housed in an individual wire cage.

The basal diets used in these studies are described in table 1.

Two organoleptic evaluations of eggs representative of the hens

TABLe 1.-Composition of the basal diets used during the laying studies

\begin{tabular}{lccc}
\hline \multicolumn{1}{c}{ Ingredients } & Study 1 & Study 2 & Study 3 \\
\hline & $\%$ & $\%$ & $\%$ \\
Corn, dent No. 2, ground & 79.2 & 75.4 & 76.2 \\
Combination of protein & 18.0 & 18.0 & 18.0 \\
$\quad$ sources & .0 & & \\
Dicalcium phosphate & 2.0 & 1.5 & 1.0 \\
Limestone, ground & .5 & .3 & 4.0 \\
NaCl & .3 & .3 & .5 \\
Premix & 15.59 & 15.09 & .3 \\
Crude protein, calculated & $1.52^{2}$ & 2.76 & 15.05 \\
Calcium, calculated & .64 & .89 & 2.71 \\
Phosphorus, calculated & & .90 \\
\hline
\end{tabular}

${ }^{1}$ Contains 0.0009 vitamins $\mathrm{A}_{0} \mathrm{D}_{3}(500,000 / 100,000 \mathrm{IU} / \mathrm{g}) ; 0.0002$ riboflavin; 0.0006 niacin; 0.0250 manganese sulfate $(75 \%) ; 0.0780$ terramycin $(6.5 \mathrm{~g}$ oxytetracycline, and 6.5 mg vitamin $B_{12} / \mathrm{kg}$ ).

${ }^{2}$ Oyster shells were offered free choice in all diets of study 1 to complement the minimum requirements of tire hens.

receiving the experimental diets in studies 1 and 3 were conducted by a trained panel, following the methods described by Kramer (3). The criteria used for evaluation were the odor of raw eggs and the flavor of soft boiled eggs. Poached eggs were omitted, because they are not commonly eaten in Puerto Rico, even though they are more sensitive for off-flavor and odor detection by a trained panel. Eggs were stored under refrigeration. The time between laying and panel evaluation never exceeded 7 days.

\section{RESULTS AND DISCUSSION}

The results obtained in the nutritional studies are shown in tables 2 and 3 . They demonstrate that a combination of about equal parts soybean and tuna meals produced the highest laying intensity and 
efficiency in studies 1 and 2. In study 3, it was similar to that obtained with a commercial feed used as control and with the diet having $6 \%$ tuna fishmeal and $3 \%$ meat meal. The results obtained in these studies are in general agreement with those obtained with growing birds of broiler and laying strains $(5,6)$.

The panel evaluations are presented in table 4. They show that eggs from all diets were acceptable from the odor or taste standpoint. No fishy or off-flavors or odors caused by diets containing levels as high as $18 \%$ of locally produced tuna fishmeal were detected. The relative cost of tuna fishmeal is the only factor that may limit its use in commercial laying diets.

TABLE 2.-Average egg production and utilization of feed for laying studies conducted at Lajas Substation

\begin{tabular}{|c|c|c|c|c|c|}
\hline \multirow{2}{*}{$\begin{array}{l}\text { Diet } \\
\text { No. }\end{array}$} & \multicolumn{3}{|c|}{ Percent composition of protein sources } & \multirow{2}{*}{$\begin{array}{l}\text { Production } \\
\text { Laying rate }\end{array}$} & \multirow{2}{*}{$\begin{array}{l}\text { Feed conversion } \\
\text { Lb feed/doz eggs }\end{array}$} \\
\hline & Soybean & Tuna & Meat & & \\
\hline \multicolumn{6}{|c|}{ Study 1 -From October to May 1966} \\
\hline 1 & 9 & 9 & 0 & $67.0 \mathrm{~A}^{2}$ & $3.51 \mathrm{~A}$ \\
\hline 2 & 0 & 9 & 9 & $63.2 \mathrm{AB}$ & $3.66 \mathrm{~A}$ \\
\hline 3 & 18 & 0 & 0 & $62.3 \mathrm{AB}$ & $3.67 \mathrm{~A}$ \\
\hline 4 & 0 & 18 & 0 & $63.9 \mathrm{AB}$ & $3.49 \mathrm{~A}$ \\
\hline 5 & 9 & 0 & 9 & 59.6AB & $3.68 \mathrm{~A}$ \\
\hline \multicolumn{6}{|c|}{ Study 2-From February io June 1967} \\
\hline 1 & 9 & 9 & & $74.7 \mathrm{a}^{2}$ & $3.24 \mathrm{a}$ \\
\hline 2 & 6 & 12 & & $72.9 \mathrm{a}$ & $3.28 \mathrm{a}$ \\
\hline 3 & 12 & 6 & & $72.8 \mathrm{a}$ & $3.27 \mathrm{a}$ \\
\hline 4 & 0 & 18 & & $65.0 \mathrm{a}$ & $3.67 \mathrm{a}$ \\
\hline 5 & 18 & 0 & & $67.3 \mathrm{a}$ & $3.48 a$ \\
\hline
\end{tabular}

${ }^{1}$ Percent laid during the experimental period expressed as 2-oz eggs.

${ }^{2}$ Means followed by the same capital letter are not significantly different at the $\mathrm{P}=.01$ level; small letter at the $\mathrm{P}=.05$ level.

TABLE 3.-Average egg production and utilization of feed for laying siudy :3 conducted at the Lajas Substation from May to October 1968

\begin{tabular}{|c|c|c|c|c|c|c|}
\hline \multirow{2}{*}{$\begin{array}{l}\text { Diet } \\
\text { No. }\end{array}$} & \multicolumn{3}{|c|}{ Percent composition of protein sources } & \multirow{2}{*}{$\begin{array}{c}\begin{array}{c}\mathrm{Egg} \\
\text { weight }\end{array} \\
\mathrm{Oz}\end{array}$} & \multirow{2}{*}{$\begin{array}{l}\text { Production } \\
\text { Laying rate }\end{array}$} & \multirow{2}{*}{$\begin{array}{l}\text { Feed conversion } \\
\text { Lb feed/doz eggs }\end{array}$} \\
\hline & Soybean & Tuna & Meat & & & \\
\hline 1 & & Commercial diet & & 25.8 & $68.2 \mathrm{~A}^{2}$ & $3.46 \mathrm{a}^{2}$ \\
\hline 2 & 9 & 6 & 3 & 24.3 & $65.2 \mathrm{~A}$ & $3.53 \mathrm{a}$ \\
\hline 3 & 9 & 9 & 0 & 24.8 & $64.9 \mathrm{~A}$ & $3.43 a$ \\
\hline 4 & 9 & 3 & 6 & 24.3 & $60.4 \mathrm{~B}$ & $3.69 b$ \\
\hline 5 & 9 & 0 & 9 & 23.7 & $54.0 \mathrm{~B}$ & $3.99 \mathrm{~b}$ \\
\hline
\end{tabular}

\footnotetext{
${ }^{1}$ Percent laid during the experimental period expressed as 2-oz eggs.

${ }^{2}$ Means followed by the same capital letter are not significantly different at the $\mathrm{P}=.01$ level, while those with the same small letters are not different at the $\mathrm{P}=.05$ level.
} 
TABLE 4.-Panel evaluation of eggs from hens fed diets containing different combinations of tuna fishmeal, meat meal with bone, and soybean meal ${ }^{1}$

\begin{tabular}{lccccc}
\hline \multicolumn{1}{c}{ Protein source } & Diet 1 & Diet 2 & Diet 3 & Diet 4 & Diet 5 \\
\hline EVALUATION 1 ${ }^{2}$ & & & & & \\
$\quad$ Soybean (\%) & 9 & 0 & 18 & 9 & 0 \\
$\quad$ Tuna (\%) & 9 & 9 & 0 & 0 & 18 \\
$\quad$ Meat (\%) & 0 & 9 & 0 & 9 & 0 \\
Average odor score $(\mathrm{n}=14)$ & $+1.1 \mathrm{a}^{3}$ & $+1.1 \mathrm{a}$ & $+1.1 \mathrm{a}$ & $+1.0 \mathrm{a}$ & $+1.1 \mathrm{a}$ \\
Average flavor score $(\mathrm{n}=14)$ & $+1.0 \mathrm{a}$ & $+1.1 \mathrm{a}$ & $+.9 \mathrm{a}$ & $+1.1 \mathrm{a}$ & $+1.0 \mathrm{a}$ \\
EVALUATION 2 & & & & & \\
$\quad$ Soybean (\%) & 9 & 9 & 9 & 9 & Commercial \\
$\quad$ Tuna (\%) & 9 & 6 & 3 & 0 & diet \\
$\quad$ Meat (\%) & 0 & 3 & 6 & 9 & $+1.3 \mathrm{a}$ \\
Average odor score $(\mathrm{n}=13)$ & $+1.2 \mathrm{a}$ & $+1.1 \mathrm{a}$ & $+1.2 \mathrm{a}$ & $+1.2 \mathrm{a}$ & $+.5 \mathrm{~b}$ \\
Average flavor score $(\mathrm{n}=14)$ & $+.6 \mathrm{ab}$ & $+1.1 \mathrm{ab}$ & $+1.4 \mathrm{a}$ & $+.8 \mathrm{ab}$ & \\
\hline
\end{tabular}

${ }^{1}$ The scale used was: Very acceptable +2 ; acceptable +1 ; questionable 0 ; slightly unacceptable -1 ; not acceptable -2 .

${ }^{2}$ Conducted on May 12, 1966, from eggs produced in study 1 described in table 2.

${ }^{3}$ Means followed by the same letter or letters are not significantly different at the $\mathrm{P}=.05$ level.

${ }^{4}$ Conducted on October 22, 1968, from eggs produced in study 3 described in table 3.

\section{RESUMEN}

Tres estudios de nutrición se llevaron a cabo durante el período de postura en los que se evaluaron diferentes combinaciones de harinas de soja, atún y carne, usando la intensidad de postura y la utilización del alimento como criterios de evaluación. También se llevaron a cabo dos evaluaciones organolépticas de los huevos en dos de los estudios.

La combinación de partes iguales de harinas de atún y soja produjo en general los resultados más satisfactorios. Segun aumentó el nivel de harina de carne en las dietas bajó la producción y se utilizó el alimento en forma menos eficiente.

En las evaluaciones organolépticas, los paneles no encontraron diferencias significativas en el sabor de los huevos duros, hervidos en agua, ni en el olor de huevos frescos sin cocinar. Esto demuestra que, en dietas comerciales para gallinas ponedoras que contengan hasta $18 \%$ de harina de atún, el único factor que puede limitar su uso es el costo relativo.

\section{LITERATURE CITED}

1. Bender, A. E., and Haizelden, S., Biological value of the protein of a variety of fish meals, Brit. J. Nutr. 11: 42-3, 1957.

2. Clark, T. B., Van Landingham, A. H., and Runnıl!, T. D., W. Va. Agr. Exp. Sta. Bull. 298, pp. 20-1, 1940.

3. Kramer, A., and Pitman, L. P., A simplified variables taste panel method for detecting flavor changes in vegetables treated with pesticides, Food Technol. 10: 155-9, 1956.

4. March, B. E., Stupich, D., and Biely, J., Evaluation of nutritional value of fish meals and meat meals, Poultry Sci. 28: 718-24, 1949.

5. Morassi, J., Soldevila, M., and Rojas-Daporta, M., Effect of different combinations of tuna fishmeal, meat meal with bone and soybean meal upon growth rate and 
utilization of feed by broilers in the starting and fattening periods, J. Agr. Univ. P.R. 54 (3): $541-50,1970$.

6. Soldevila, M., Morassi, J., and Rojas-Daporta, M., Effect of various protein sources on the growth rate and utilization of feed of female chicks of laying strains, J. Agr. Univ. P.R. 60 (4): , 1976.

7. —_Lefebre-González, L., and Morassi, J., Palatability of meat from chickens raised on diets containing different levels of tuna and meat meals. Evaluation by a trained panel, J. Agr. Univ. P.R. 54 (1): 50-6, 1970.

8. Summers, J. D., Slinger, S. J., and Ashton, G. C., Evaluation of meat meal as a protein supplement for the chick, Can. J. Anim. Sci. 44: 228-34, 1964.

9. Waldroup, P. W., Van Wallenghen, P., Fry, J. L., Chicco, C., and Harms, R. H., Fishmeals studies: Effects of levels and sources on broiler growth rate and feed efficiency, Poultry Sci. 44: 1012-6, 1965. 